\title{
PENGARUH KOMPETENSI TERHADAP KINERJA KARYAWAN PADA PT. BANK DANAMON INDONESIA, TBK CABANG SIMPANG PASAR BAWAH
}

\author{
Nana Dianita \\ Sekolah Tinggi Ilmu Ekonomi Prakarti Mulya \\ E-mail: nanaceeamoy@yahoo.co.id
}

\begin{abstract}
The purpose of this study was to determine the effect of competence on the performance of employees at PT. Bank Danamon Indonesia, Tbk Cabang Simpang Pasar Bawah. The sample in this study were all employees at PT. Bank Danamon Indonesia, Tbk Cabang Simpang Pasar Bawah totaling 34 people. While the variables studied in this research is the competence and performance. Analysis of data using simple linear regression method using validity, reliability, $R 2$ and t test. The tests are conducted to determine the relationship between the independent variables (independent variables) and dependent variable (dependent variable). Based on research results the effect of competence on the performance of employees with correlation value $R=0,656$ which indicates a close relationship between the effect of competence on the performance of employees at PT. Bank Danamon Indonesia, Tbk Cabang Simpang Pasar Bawah. While the R-square at 0,430 which can competence has contributed of $43 \%$ to the performance of employees at. Bank Danamon Indonesia, Tbk Cabang Simpang Pasar Bawah. Partially acquired competence variable positive and significant effect on the performance employees at. Bank Danamon Indonesia, Tbk Cabang Simpang Pasar Bawah with simple linear regression equation as follows: $Y=18,342+0,627 X$ significantly smaller 0,000 than alpha 0,05. The conclusion of this study that partial hypothesis between variables competence on performance employees is proven and can be accepted as true
\end{abstract}

Keywords: Competence, Performance

\section{A. PENDAHULUAN}

Karyawan merupakan salah satu faktor penentu dalam proses pembagunan yang dinamis sehingga dibutuhkan perannya yang lebih besar untuk memajukan perusahaan. Karyawan sebagai unsur utama sebagai sumber daya manusia mempunyai peran penting dalam menentukan keberhasilan suatu perusahaan. Oleh karena itu tidak dapat dipungkiri bahwa faktor manusia merupakan modal utama yang perlu diperhatikan dalam suatu perusahaan, hal ini dikarenakan sangatlah penting karena keberhasailan suatu perusahaan ditentukan oleh kualitas dan kemampuan para karyawan. Karyawan perlu dikelola secara professional agar terwujud suatu keseimbangan antara kebutuhan karyawan dengan tuntutan dan kemampuan perusahaan. Karyawan sebagai faktor tenaga kerja dapat tumbuh dan berkembang dengan baik, bersemangat dalam melakukan aktivitas serta dapat bekerja keras demi mencapai tujuan yang diinginkan oleh perusahaan, hal tersebut tidak luput dari perhatian perusahaan terhadap para karyawannya. Untuk mencapai tujuan perusahaan, diperlukan kemampuan dalam memanfaatkan sumber daya yang ada, sehingga mempunyai tingkat hasil dan daya guna yang tinggi yang dapat meningkatkan kinerja perusahaan.

Pengelolaan karyawan salah satunya melalui pendidikan dan pelatihan yang dberikan oleh perusahaan yang bertujuan untuk mendorong karyawan bekerja lebih giat untuk meningkatkan kinerja karyawan. Pendidikan dan pelatihan dianggap perlu bagi perusahaan sebagai suatu investasi dalam sumber daya manusia yang diharapkan dapat meningkatkan kinerja perusahaan. Melalui proses pendidikan dan pelatihan tersebut diharapkan kompetensi karyawan dapat lebih meningkat demi tercapinya standarisasi kompetensi yang dibutuhkan perusahaan untuk mencapai targer yang telah direncanakan.

Berikut ini adalah data karyawan PT. Bank Danamon Indonesia, Tbk Cabang Simpang Pasar Bawah Tahun 2014-2018 : 
Tabel 1. Jumlah Karyawan PT. Bank Danamon Indonesia, Tbk Cabang Simpang Pasar Bawah Tahun 2014-2018

\begin{tabular}{|c|c|}
\hline Tahun & Jumlah Karyawan \\
\hline 2014 & 29 \\
\hline 2015 & 33 \\
\hline 2016 & 35 \\
\hline 2017 & 36 \\
\hline 2018 & 34 \\
\hline
\end{tabular}

Sumber : PT. BDI, Tbk Cabang Simpang Pasar Bawah, 2019.

Dari tabel 1 dapat dilihat jumlah karyawan PT. Bank Danamon Indonesia, Tbk Cabang Simpang Pasar Bawah dari tahun 2017-2018 mengalami penurunan. Penurunan jumlah karyawan disebabkan oleh beberapa faktor sehingga perusahaan melakukan beberapa langkah yang salah satunya melakukan peningkatan pelayanan kepada nasabah agar kinerja yang diharapkan oleh perusahaan dapat tercapai dengan maksimal.

Dari tabel dibawah ini dapat dilihat jumlah pendidikan dan pelatihan yang diberikan oleh PT. Bank Danamon Indonesia, Tbk Cabang Simpang Pasar Bawah kepada para karyawannya sesuai dengan tugas dan tanggung jawabnya dari tahun 2014-2018 :

Tabel 2 Data Karyawan Yang Mendapat Pendidikan Dan Pelatihan (Training Kerja) Pada PT. Bank Danamon Indonesia, Tbk Cabang Simpang Pasar Bawah Tahun 2014-2018

\begin{tabular}{|l|c|c|c|c|c|}
\hline \multicolumn{1}{|c|}{ Bagian Divisi } & \multicolumn{5}{|c|}{ Tahun } \\
\cline { 2 - 6 } & $\mathbf{2 0 1 4}$ & $\mathbf{2 0 1 5}$ & $\mathbf{2 0 1 6}$ & $\mathbf{2 0 1 7}$ & $\mathbf{2 0 1 8}$ \\
\hline Branch Manager & 2 & 2 & 2 & 2 & 2 \\
\hline Manajer Operasional & 2 & 3 & 2 & 2 & 1 \\
\hline Manajer Marketing & 3 & 2 & 2 & 2 & 2 \\
\hline Head Teller & 2 & 2 & 1 & 1 & 1 \\
\hline Head Sales Service Officer & 2 & 2 & 1 & 2 & 1 \\
\hline Teller & 2 & 2 & 2 & 1 & 2 \\
\hline Marketing & 3 & 3 & 2 & 1 & 2 \\
\hline Sales Service Officer & 3 & 1 & 1 & 1 & 2 \\
\hline \multicolumn{1}{|r|}{ Jumlah } & $\mathbf{1 9}$ & $\mathbf{1 7}$ & $\mathbf{1 3}$ & $\mathbf{1 2}$ & $\mathbf{1 3}$ \\
\hline
\end{tabular}

Sumber : PT. BDI, Tbk Cabang Simpang Pasar Bawah, 2019.

Dari tabel 2 dapat dilihat jumlah pendidikan dan pelatihan yang diberikan oleh PT. Bank Danamon Indonesia, Tbk Cabang Simpang Pasar Bawah pada tahun 2014-2015 mengalami penurunan sebanyak 2 kali, tahun 2016 mengalami penurunan sebanyak 4 kali,

Eko dan Bisnis (Riau Economics and Business Reviewe) Volume 10, Nomor 3, 27 September 2019 tahun 2017 mengalami penurunan sebanyak 1 kali sedangkan pada tahun 2018 juga mengalami peningkatan sebanyak 2 kali. Peningkatan pemberian pendidikan dan pelatihan yang diberikan PT. Bank Danamon Indonesia, Tbk Cabang Simpang Pasar Bawah bertujuan untuk meningkatkan kompetensi yang dimiliki karyawannya sehingga dapat memberikan jasa pelayanan yang lebih baik bagi para nasabah serta dapat meningkatkan kinerja perusahaan.

Kompetensi yang dimiliki karyawan tidak hanya didapat dari pelatihan yang diberikan oleh perusahaan tetapi juga didapat dari pendidikan formal yang dimiliki karyawan. Berikut ini dapat dilihat pendidikan formal yang dimiliki karyawan PT. Bank Danamon Indonesia, Tbk Cabang Simpang Pasar Bawah tahun 2018 :

Tabel 3 Pendidikan Karyawan PT. Bank Danamon Indonesia, Tbk Cabang Simpang Pasar Bawah Tahun 2018

\begin{tabular}{|c|c|c|}
\hline Kategori & Jumlah & $\begin{array}{c}\text { Persentase } \\
(\mathbf{\%})\end{array}$ \\
\hline SMA & 3 & $8,82 \%$ \\
\hline Diploma 3 & 10 & $29,41 \%$ \\
\hline Strata 1 & 21 & $61,77 \%$ \\
\hline Jumlah & $\mathbf{3 4}$ & $\mathbf{1 0 0 \%}$ \\
\hline
\end{tabular}

Sumber : PT. BDI, Tbk Cabang Simpang Pasar Bawah, 2019.

Dari table 3 dapat dilihat pendidikan karyawan PT. Bank Danamon Indonesia, Tbk Cabang Simpang Pasar Bawah paling banyak adalah Strata I (41,18\%). Hal ini menunjukkan bahwa pendidikan yang dimiliki karyawan dapat membantu dalam melakukan pekerjaan.

Dari tabel dibawah ini dapat dilihat hasil kerja karyawan PT. Bank Danamon Indonesia, Tbk Cabang Simpang Pasar Bawah, yang telah diperoleh dari tahun 2014-2018 : 
Tabel 4 Jumlah Target Yang Diberikan Serta Dana Yang Dikeluarkan PT. Bank Danamon Indonesia, Tbk Cabang Simpang Pasar Bawah Tahun 2014-2018

\begin{tabular}{|c|c|c|c|}
\hline Tahun & $\begin{array}{c}\text { Target } \\
\text { (Tahun) }\end{array}$ & $\begin{array}{c}\text { Realisasi } \\
\text { (Tahun) }\end{array}$ & $\begin{array}{c}\text { Pencapaian } \\
(\%)\end{array}$ \\
\hline 2014 & 52.500 .000 .000 & 53.769 .000 .000 & $102,42 \%$ \\
\hline 2015 & 55.000 .000 .000 & 58.657 .000 .000 & $106,65 \%$ \\
\hline 2016 & 60.000 .000 .000 & 53.654 .000 .000 & $89,42 \%$ \\
\hline 2017 & 65.000 .000 .000 & 60.054 .000 .000 & $92,39 \%$ \\
\hline 2018 & 66.000 .000 .000 & 59.760 .500 .000 & $90,55 \%$ \\
\hline
\end{tabular}

Sumber : PT. BDI, Tbk Cabang Simpang Pasar Bawah, 2019.

Dari tabel 4 dapat dilihat hasil laporan kinerja karyawan PT. Bank Danamon Indonesia, Tbk Cabang Simpang Pasar Bawah dalam beberapa tahun belum mencapai $100 \%$ sehingga dikatakan belum maksimal. Hal ini disebabkan oleh menurunnya kinerja karyawan PT. Bank Danamon Indonesia, Tbk Cabang Simpang Pasar Bawah yang diindikasi karena kurangnya kompetensi yang dimiliki karyawan dalam melakukan pekerjaannya.

\section{Pengertian Manajemen Sumber Daya Manusia}

Manajemen sumber daya manusia (MSDM) merupakan bidang strategis dari organisasi.Manajemen sumber daya manusia (MSDM) dapat diartikan sebagai kegiatan perencanaan, pengadaan, pengembangan, pemeliharaan serta penggunaan SDM untuk mencapai tujuan yang baik secara individu maupun organisasi. (Edy Sutrisno, 2015:6) Manajemen sumber daya manusia adalah mengelola sumber daya manusia yang sangat berpengaruh terhadap upaya organisasi dalam mencapai tujuannya. Manajemen sumber daya manusia adalah seni dan ilmu pengadaan, pengembangan dan pemanfaatan sumber daya manusia sehingga tujuan organisasi direalisasi secara daya guna dan adanya kegairahan kerja dari semua tenaga kerja. (M. Manullang, 2009:198)

Manajemen sumber daya manusia adalah ilmu dan seni mengatur hubungan dan peranan tenaga kerja agar efektif dan efesien membantu terwujudunya tujuan perusahaan, karyawan dan masyarakat. (Melayu S.P Hasibuan, 2012:10) Manajemen kepegawaian dan sumber daya manusia

Eko dan Bisnis (Riau Economics and Business Reviewe) Volume 10, Nomor 3, 27 September 2019 sangat penting bagi perusahaan dalam mengelola, mengatur dan memanfaatkan pegawai sehingga dapat berfungsi secara produktif untuk tercapainya tujuan perusahaan. Manajemen sumber daya manusia dapat didefenisikan sebagai suatu pengelolaan dan pendayagunaan sumber daya yang ada pada individu (pegawai). (Anwar Prabu Mangkunegara, 2011:2)

\section{Pengertian Kompetensi}

Menurut Spencer dan Spencer dalam Ellitan dan Anatan (2009:27) kompetensi adalah karakteristik, sikap dan prilaku atau kemampuan individu yang relatif stabil ketika menghadapi situasi kerja. Menurut Dharma (2012:102) kompetensi adalah apa yang dibawa oleh seseorang ke dalam pekerjaannya dalam bentuk jenis dan tingkatan perilaku yang berbeda.

Sedangkan menurut Spencer dan Spencer dalam Sutrisno (2015:203) kompetensi adalah bagian kepribadian yang mendalam dan melekat kepada seseorang serta prilaku yang dapat diprediksi pada berbagai keadaan dan tugas pekerjaan. Kompetensi merujuk pada karakteristik yang mendasari prilaku yang menggambarkan motif, karakteristik pribadi (ciri khas), konsep diri, nilai-nilai, pengetahuan atau keahlaian yang dibawa seseorang yang berkinerja unggul. (Spencer dan Spencer dalam Palan, 2007:6)

Kompetensi adalah suatu kemampuan untuk melaksanakan atau melakukan suatu pekerjaan atau tugas yang dilandasi atas keterampilan dan pengetahuan serta didukung oleh sikap kerja yang dituntut oleh pekerjaan tersebut. (Wibowo, 2007:86)

Menurut Gordon dalam Sutrisno (2015:204-205), menjelaskan beberapa aspek yang terkandung dalam konsep kompetensi, yaitu :

1. Pengetahuan (knowledge) yaitu kesadaran dalam bidang kognitif.

2. Pemahaman (understanding) yaitu kedalaman kognitif dan afektif yang dimiliki oleh individu.

P.ISSN: 1410-7988 E.ISSN: 2614-123X 
3. Kemampuan (skill) adalah sesuatu yang dimiliki oleh individu untuk melaksanakan tugas atau pekerjaan yang dibebankan kepadanya.

4. Nilai (value) adalah suatu standar prilaku yang telah diyakini dan secara psikologi telah menyatu dalam diri seseorang.

5. Sikap (attitude) yaitu perasaan atau reaksi terhadap suatu rangsangan yang datang dari luar.

6. Minat (interest) adalah kecenderungan seseorang untuk melakukan suatu perbuatan.

\section{Komponen-Komponen Kompetensi}

Komponen-komponen kompetensi
menurut Spencer dalam Sudarmanto
$(2015: 53)$, yaitu :

1. Motives, adalah sesuatu di mana seseorang secara konsisten berpikir sehingga ia melakukan tindakan. Motif menggerakkan, mengarahkan dan menyeleksi prilaku terhadap kegiatan atau tujuan tertentu dan menjauh dari yang lain.

2. Traits, adalah karakteristik-karakteristik fisik dan respons-respons konsisten terhadap berbagai situasi dan informasi.

3. Self concept, adalah sikap, nilai-nilai dan citra diri yang dimiliki seseorang.

4. Knowledge, adalah pengetahuan atau informasi seseorang dalam bidang spesifik tertentu.

5. Skill, adalah kemampuan untuk melaksanakan suatu tugas fisik tertentu atau mental tertentu.

\section{Faktor-Faktor Yang Mempengaruhi Terbentuknya Kompetensi}

Terdapat tujuh determinan yang mempengaruhi terbentuknya kompetensi, yakni : (Zwell dalam Sudarmanto, 2015:5457)

1. Kepercayaan dan nilai. Kepercayaan dan nilai seseorang terhadap sesuatu sangat berpengaruh terhadap sikap dan perilaku seseorang.Seseorang yang memiliki nilai dan kepercayaan diri tidak kreatif dan inovatif cenderung tidak berpikir dan

Eko dan Bisnis (Riau Economics and Business Reviewe) Volume 10, Nomor 3, 27 September 2019 bersikap untuk menemukan sesuatu yang baru dan menantang bagi dirinya.

2. Keahlian atau keterampilan. Aspek ini memegang peranan sangat penting dalam membentuk kompetensi.

3. Pengalaman. Pengalaman merupakan elemen penting dalam membentuk penguasaan kompetensi seseorang terhadap tugas.

4. Karakteristik personal. Karakteristik kepribadian seseorang turut berpengaruh terhadap kompetensi seseorang.

5. Motivasi. Motivasi seseorang terhadap suatu pekerjaan atau aktifitas akan berpengaruh terhadap hasil yang dicapai.Motivasi merupakan faktor kompetensi yang sangat penting. Motivasi merupakan faktor yang cenderung dapat diubah.

6. Isu-isu emosional. Hambatan dan blokblok emosional sering kali membatasi penguasaan kompetensi.

7. Kapasitas intelektual. Kapasitas intelektual seseorang akan berpengaruh terhadap penguasaan kompetensi. Kompetensi tergantung pada kemampuan kognitif seperti berpikir konseptual dan berpikir analitis.

\section{Manfaat Penggunaan Kompetensi}

Ruky dalam Sutrisno (2015:208209), mengemukakan konsep kompetensi menjadi menjadi semakin popular dan sudah banyak digunakan oleh perusahaanperusahaan besar dengan berbagai alasan, yaitu :

1. Memperjelas standar kerja dan harapan yang ingin dicapai. Dalam hal ini, model kompetensi akan mampu menjawab dua pertanyaan mendasar : keterampilan, pengetahuan dan karakteristik apa saja yang dibutuhkan pekerjaan dan perilaku apa saja yang berpengaruh langsung dengan prestasi kerja.

2. Alat seleksi karyawan. Penggunaan kompetensi standar sebagai alat seleksi dapat membantu organisasi untuk memilih calon karyawan terbaik.

P.ISSN: 1410-7988 E.ISSN: 2614-123X 
3. Memaksimalkan produktivitas. Tuntutan untuk menjadikan suatu organisasi "ramping" mengharuskan kita untuk mencari karyawan yang dapat dikembangkan secara terarah untuk menutupi kesenjangan dalam keterampilannya sehingga mampu untuk dimobilisasikan secara vertical maupun horizontal.

4. Dasar untuk pengembangan sistem remunerasi. Model kompetensi dapat digunakan untuk mengembangkan sistem remunerasi (imbalan) yang akan dianggap lebih adil.

5. Memudahkan adaptasi terhadap perubahan. Dalam era perubahan yang sangat cepat, sifat dari suatu pekerjaan sangat cepat berubah dan kebutuhan akan kemampuan bar uterus meningkat.

6. Menyelaraskan perilaku kerja dengan nilai-nilai organisasi. Model kompetensi merupakan cara yang paling mudah untuk mengomunikasikan nilai-nilai dan hal-hal apa saja yang harus menjadi fokus dalam unjuk kerja karyawan.

\section{Indikator Kompetensi}

Menurut Armstrong dalam Sudarmanto (2015:68) indikator kompetensi dapat dilihat sebagai berikut :

1. Kemampuan intelektual, meliputi : perspektif strategis, analisis dan penilaian, perencanaan dan pengorganisasian.

2. Kemampuan interpersonal, meliputi : mengelola staf, sikap persuasif dan asertif, pengambilan keputusan, kepekaan interpersonal dan komunikasi lisan.

3. Kemampuan adaptabilitas, meliputi : adaptasi.

4. Kemampuan orientasi hasil, meliputi : sikap energik dan inisiatif, motivasi berprestasi dan kepekaan bisnis.

\section{Pengertian Kinerja}

Menurut Wibowo (2013:7) kinerja merupakan hasil pekerjaan yang mempunyai hubungan kuat dengan tujuan strategi organisasi, kepuasan konsumen, dan

Eko dan Bisnis (Riau Economics and Business Reviewe) Volume 10, Nomor 3, 27 September 2019 memberikan kontribusi pada ekonomi. Dengan demikian, kinerja adalah tentang melakukan pekerjaan tersebut. Kinerja adalah tentang apa yang dikerjakan dan bagaimana cara mengerjakannya. Menurut Mangkunegara (2011:67) mengungkapkan bahwa istilah kinerja berasal dari kata job performance atau actual performance (prestasi kerja atau prestasi sesungguhnya yang dicapai seseorang).

Kinerja diartikan sebagai prestasi, menunjukkan suatu kegiatan atau perbuatan dan melaksanakan tugas yang dibebankan.Pengertian kinerja sering diidentikkan dengan prestasi kerja. (Supardi, 2013:45) Kinerja adalah apa yang dapat dikerjakan oleh seseorang sesuai dengan tugas dan fungsinya. (Gilbert dalam Notoatmodjo, 2009:124)Prestasi kerja adalah suatu hasil kerja yang dicapai seseorang dalam melaksanakan, menyelesaikan pekerjaan yang dibebankan kepadanya. (Sunyoto, 2012:18)

\section{Evaluasi Kinerja Appraisal)}

Evaluasi kinerja merupakan sistem formal yang digunakan untuk mengevaluasi kinerja pegawai secara periodik yang ditentukan oleh organisasi. Evaluasi kinerja mempunyai tujuan antara lain : (Ivancevich dalam Surya Dharma, 2012:14-15)

1. Pengembangan. Dapat digunakan untuk menentukan pegawai yang perlu detraining dan membantu evaluasi hasil training.

2. Pemberian Reward. Dapat digunakan untuk proses penentuan kenaikan gaji, insentif dan promosi.

3. Motivasi. Dapat digunakan untuk memotivasi pegawai, mengembangkan inisiatif, rasa tanggung jawab sehingga mereka terdorong untuk meningkatkan kinerjanya

4. Perencanaan SDM. Dapat bermanfaat bagi pengembangan keahlian dan keterampilan serta perencanaan SDM.

5. Kompensasi. Dapat memberikan informasi yang digunakan untuk menentukan apa yang harus diberikan

P.ISSN: 1410-7988 E.ISSN: 2614-123X 
kepada pegawai yang berkinerja tinggi atau rendah dan bagaimana prinsip pemberian kompensasi yang adil.

6. Komunikasi. Evaluasi merupakan dasar untuk komunikasi yang berkelanjutan antara atasan dan bawahan menyangkut kinerja pegawai.

\section{Tujuan Manajemen Kinerja}

Tujuan umum manajemen kinerja adalah untuk menciptakan budaya para individu dan kelompok memikul tanggung jawab bagi usaha peningkatan proses kerja dan kemampuan yang berkesinambungan. Secara khusus dan spesifik, manajemen kinerja bertujuan untuk : (Surya Dharma, 2012:29)

1. Memperoleh peningkatan kinerja yang berkelanjutan.

2. Bertindak sebagai daya dongkrak untuk perubahan yang lebih berorientasi kinerja.

3. Meningkatkan motivasi dan komitmen guru.

4. Memungkinkan individu untuk mengembangkan kemampuan, meningkatkan kepuasan kerja dan mencapai potensi pribadi yang bermanfaat bagi individu dan organisasi.

5. Mengembangkan hubungan yang terbuka dan konstruktif antara individu dan pimpinan dalam suatu proses dialog yang berkesinambungan terkait dengan pekerjaan yang dilakukan sepanjang tahun.

6. Menyediakan suatu kerangkan kerja bagi kesepakatan sasaran.

\section{Manfaat Manajemen Kinerja}

Bagi suatu perusahaanatau organisasi penilaian kinerja memiliki berbagai manfaat antara lain : (Wilson Bangun, 2012: 233)

1. Evaluasi antar individu dalam organisasi. Penilaian kinerja dapat bertujuan untuk menilai kinerja setiap individu dalam organisasi.Tujuan ini dapat memberi manfaat dalam menentukan jumlah danjenis kompensasi yang merupakan hak bagi setiap individu dalam organisasi.

Eko dan Bisnis (Riau Economics and Business Reviewe) Volume 10, Nomor 3, 27 September 2019
2. Pengembangan diri setiap individu dalam organisasi. Penilaian kinerja pada tujuan ini bermanfaat untuk pengembangan guru.Setiap individu dalam organisasi dinilai kinerjanya, bagi guru yang memiliki kinerja rendah perlu dilakukan pengembangan baik melalui pendidikan atau pelatihan.

3. Pemeliharaan system. Berbagai sistem yang ada dalam organisasi, setiap subsistem yang ada saling berkaitan antara subsistem dengan subsistem lainnya. Salah satu subsistem yang tidak berfungsi dengan baik akan mengganggu jalannya subsistem yang lain.

4. Dokumentasi. Penilaian kinerja akan memberi manfaat sebagai dasar tindak lanjut dalam posisi pekerjaan guru di masa akan datang. Manfaat penilaian kinerja disini berkaitan dengan keputusan-keputusan manajemen sumber daya manusia, pemenuhan secara legal manajemen sumber daya manusia dan sebagai kriteria pengujian validitas.

\section{Indikator Kinerja Karyawan}

Untuk memudahkan pengkajian kinerja karyawan, Mangkunegara (2011:75) mengemukakan indikator-indikator kinerja yaitu sebagai berikut:

1. Kualitas Kerja. Kualitas kerja terdiri dari ketepatan, ketelitian, keterampilan dan kebersihan karyawan dalam melakukan pekerjaan

2. Kuantitas. Kuantitas kerja terdiri dari output serta seberapa cepat bisa menyelesaikan pekerjaan yang diberikan oleh perusahaan.

3. Dapat Tidaknya Diandalkan. Terdiri dari seberapa besar karyawan bisa mengikuti instruksi, inisiati, hati-hati dan kerajinan karyawan dalam bekerja.

4. Sikap. Sikap terhadap perusahaan serta karyawan lainnya dalam melakukan pekerjaan serta kerjasama dalam menyelesaikan tugas yang diberikan. 
Pengaruh Kompetensi Terhadap Kinerja Karyawan

Kompetensi terdiri dari pengetahuan (knowledge), keahlian (skill) dan prilaku (attitude). Kinerja secara jelas dipengaruhi oleh bagaimana orang-orang menanggapi dan mempengaruhi pekerjaannya. Sedangkan beberapa faktor lain yang mempengaruhi kinerja karyawan yaitu kemauan kerja, kemampuan kerja, lingkungan kerja, penghasilan, jaminan sosial, kondisi kerja dan hubungan kerja. (Sinugan dalam M. Ali Fitran, 2012:21) Menurut Dharma (2012:103) kompetensi dapat mempengaruhi aspek-aspek kinerja seseorang dalam suatu pekerjaan.

\section{METODE}

\section{Lokasi Penelitian}

Dalam penelitian ini penulis mengambil lokasi pada PT. Bank Danamon Indonesia, Tbk Cabang Simpang Pasar Bawah yang beralamat di JL. M. Yamin No. 65 Kel. Kampung Dalam Kec. Senapelan Pekanbaru-Riau.

\section{Jenis Dan Sumber Data}

Adapun jenis data yang penulis kumpulkan dalam penulisan skripsi ini adalah :

Data Primer. Data Primer yaitu data yang langsung diperoleh dari objek penelitian. (Sugiyono, 2010:14) Melalui kuisioner dan wawancara langsung dengan pimpinan dan karyawan PT. Bank Danamon Indonesia, Tbk Cabang Simpang Pasar Bawah.

Data Skunder. Data skunder yaitu data yang penulis peroleh dari sumber data yang ada kaitannya dengan penelitian ini. (Sugiyono, 2010:14) Berupa data yang sudah tersedia seperti data jumlah karyawan, struktur organisasi dan aktifitas perusahaan serta data lainnya yang mendukung analisa dalam penelitian ini.

\section{Teknik Pengumpulan Data}

Dalam penulisan skripsi ini, penulis menggunakan cara pengumpulan data sebagai berikut :

Eko dan Bisnis (Riau Economics and Business Reviewe) Volume 10, Nomor 3, 27 September 2019
Kuisioner. Kuisioner adalah daftar pertanyaan yang disebarkan kepada seluruh karyawan pada PT. Bank Danamon Indonesia, Tbk Cabang Simpang Pasar Bawah. Untuk mengetahui pengaruh kompetensi terhadap kinerja karyawan digunakan skala likert. Dalam penelitian ini, skala pengukuran yang di gunakan adalah skala likert. Menurut Sugiyono (2010:135) skala likert adalah di gunakan untuk mengukur sikap, pendapat, dan persepsi seseorang atau sekelompok orang.

Wawancara. Wawancara adalah mengadakan wawancara langsung dengan pimpinan perusahaan tentang berbagai informasi/data, untuk bahan analisa yang diperlukan dalam penulisan skripsi ini.

\section{Populasi Dan Sampel}

Populasi adalah keseluruhan subjek penelitian. Apabila seseorang ingin meneliti semua elemen yang ada dalam wilayah penelitian, maka penelitiannya disebut penelitian populasi. (Suharsimi Arikunto, 2010:173) Populasi dalam penelitian ini adalah jumlah karyawan PT. Bank Danamon Indonesia, Tbk Cabang Simpang Pasar Bawah yang berjumlah 34 orang.

Sampel adalah sebagian atau wakil populasi yang diteliti. Jika kita hanya akan meneliti sebagian dari populasi, maka penelitian tersebut disebut penelitian sampel. (Suharsimi Arikunto, 2010: 174) Sedangkan teknik pengambilan sampel ditentukan secara sensus yaitu mengambil seluruh populasi yang digunakan sebagai sampel karena jumlah populasai < 100 . (Suharsimi Arikunto, 2010: 174) Jadi sampel yang diambil dalam penelitian ini adalah seluruh karyawam yang ada pada PT. Bank Danamon Indonesia, Tbk Cabang Simpang Pasar Bawah yang berjumlah 34 orang karena pimpinan tidak termasuk dalam penelitian ini.

\section{Metode Analisis Data \\ Uji Instrument Data}

Untuk menunjukan sejauh mana instrument penelitian dapat dipercaya dan 
dilakukan dengan dua pengamatan yaitu pengujian validitas dan reliabilitas dilakukan untuk mengukur apakah pertanyaanpertanyaan yang digunakan untuk mengukur indikator dalam kuisioner telah memenuhi persyaratan secara statistik atau tidak.

Uji Reliabilitas. Uji reliabilitas berguna untuk menetapkan apakah instrumen yang dalam hal ini kuesioner dapat digunakan lebih dan satu kali, paling tidak oleh responden yang sama akan menghasilkan data yang konsisten. Dengan kata lain, reliabilitas instrumen mencirikan tingkat konsistensi. Nilai koefisien reliabilitas yang baik adalah diatas 0,6 (kuat), di atas 0,8 (sangat kuat). (Sugiyono, 2010:214)

Uji Normalitas. Uji ini bertujuan untuk menguji apakah dalam model regresi mempunyai distribusi data normal atau mendekati normal. Jika data menyebar disekitar garis diagonalnya dan mengikuti arah garis diagonalnya/grafik histogram maka menunjukkan pola distribusi normal (Imam Ghozali, 2005:35)

\section{Regresi Linear Sederhana}

Analisis regresi sederhana adalah analisis untuk mengukur besarnya pengaruh antara satu variabel independen dengan satu variabel dependen. Analisis ini digunakan untuk mengetahui arah hubungan antara variabel independen dengan variabel dependen apakah positif atau negatif dan untuk memprediksi nilai dari variabel dependen apabila nilai variabel independen mengalami kenaikan atau penurunan. Data yang digunakan biasanya berskala interval atau rasio. Rumus regresi linear sederhana menurut Sugiyono (2010:270) adalah sebagai berikut :

$$
\mathrm{Y}=\mathrm{a}+\mathrm{bX}+\varepsilon
$$

Keterangan :

$\mathrm{Y}=$ Kinerja Karyawan.

a = Nilai Y apabila $\mathrm{X}=0$ (harga konstan)

$\mathrm{b}=$ Koefisien regresi

$\mathrm{X}=$ Kompetensi.

$\varepsilon=$ Standart Eror

\section{Uji Hipotesis (Uji t)}

Eko dan Bisnis (Riau Economics and Business Reviewe) Volume 10, Nomor 3, 27 September 2019
Digunakan untuk mengetahui pengaruh dan masing-masing variabel, baik variabel bebas terhadap variabel terikat yang signifikan secara statistik. Langkahlangkah pengujian uji $\mathrm{t}$ sebagai berikut : (Duwi Priyatno, 2008:57-58)

Menentukan Hipotesis. $\mathrm{H}_{0}$ : Tidak ada hubungan secara signifikan antara variabel independent dengan variabel dependent. $\mathrm{H}_{\mathrm{a}}$ : Ada hubungan secara signifikan antara variabel independent dengan variabel dependent.

Menentukan tingkat signifikan. Pengujian menggunakan uji dua sisi dengan tingkat signifikan a $=5 \%$ (uji dilakukan 2 sisi karena untuk mengetahui ada atau tidaknya hubungan yang signifikan, jika 1 sisi digunakan untuk mengetahui hubungan lebih kecil atau lebih besar).

Menentukan $\mathrm{t}$ hitung, Menentukan $\mathrm{t}$ table. Tabel distribusi t dicari pada $\mathrm{a}=5 \%$ $: 2=2,5 \%$ (uji 2 sisi) dengan derajat kebebasan $(\mathrm{df})=\mathrm{n}-\mathrm{k}-1$

Kriteria Pengujian. $\mathrm{H}_{\mathrm{o}}$ diterima jika $-\mathrm{T}$ Tabel $<\mathrm{T}$ hitung $<\mathrm{T}$ table. $\mathrm{H}_{\mathrm{o}}$ ditolak jika $-\mathrm{T}$ Hitung $<\mathrm{T}$ Tabel atau T Hitung $>\mathrm{T}$ Tabel

Berdasarkan probabilitas : $\mathrm{H}_{0}$ diterima jika $\mathrm{P}$ value $>0,05 . \mathrm{H}_{\mathrm{o}}$ ditolak jika $\mathrm{P}$ value $<0,05$

Membandingkan $\mathrm{t}$ hitung dengan $\mathrm{t}$ tabel dan probabilitas.

\section{Analisis Determinasi $\left(\mathbf{R}^{\mathbf{2}}\right)$}

Analisis determinasi dalam regresi linear sederhana yang digunakan untuk mengetahui persentase sumbangan pengaruh variabel independen terhadap variabel dependen. Koefisien ini menunjukkan seberapa besar persentase variasi variabel independen yang digunakan dalam model dan mampu menjelaskan variasi variabel dependen. $\mathrm{R}^{2}$ sama dengan 0 , maka tidak ada sedikitpun persentase sumbangan pengaruh yang diberikan variabel independen terhadap variabel dependen atau variasi variabel independen yang digunakan dalam model tidak menjelaskan sedikitpun variasi variabel dependen. Sebaliknya $\mathrm{R}^{2}$ sama dengan 1,

P.ISSN: 1410-7988 E.ISSN: 2614-123X 
maka persentase sumbangan pengaruh yang diberikan variabel independen terhadap variabel dependen adalah sempurna, atau variasi variabel independen yang digunakan dalam model menjelaskan $100 \%$ variasi variabel dependen.

\section{HASIL}

\section{Uji Reliabilitas}

Pengujian reliabilitas dalam penelitian ini adalah dengan menggunakan rumus Cronbach Alpha. Hasil pengujian reliabilitas untuk masing-masing item yang dilihat dari tabel 5 berikut ini :

\section{Tabel 5 Hasil Pengujian Reliability}

\section{Variabel}

\begin{tabular}{|c|c|c|}
\hline Variabel & Cronbac's Alpha & N of Item \\
\hline Kompetensi (X) & 0,886 & 12 \\
Kinerja Karyawan (Y) & 0,878 & 12 \\
\hline
\end{tabular}

Sumber : Data Olahan SPSS. 17, 2019.

Dari tabel 5 dapat dlihat kedua variabel mempunyai koefisien alpha yang cukup besar yaitu di atas 0,8 (sangat kuat) sehingga dapat dikatakan semua konsep pengukuran masing-masing variabel dari kuisioner adalah reliable yang berarti bahwa kuisioner yang digunakan dalam penelitian ini adalah kuisioner yang handal.

\section{Uji Normalitas}

Uji ini bertujuan untuk menguji apakah dalam model regresi, variabel dependen dan variabel independent mempunyai distribusi data normal atau mendekati normal. Kita dapat melihatnya dari normal probability plot yang membentuk suatu garis diagonal dan ploting data yang akan dibandingkan dengan garis diagonalnya. Jika data menyebar disekitar garis diagonal dan mengikuti arah garis diagonal/grafik histogram maka menunjukkan pola distribusi normal. Apabila data jauh dari garis diagonal dan atau tidak mengikuti arah garis diagonal/grafik histogram maka menunjukkan pola distribusi tidak normal.

Berikut hasil uji normalitas dari hasil penelitian pada PT. Bank Danamon Indonesia, Tbk Cabang Simpang Pasar Bawah yang dapat dilihat pada gambar berikut ini :

\section{Gambar 5.1 :Hasil Uji Normalitas}

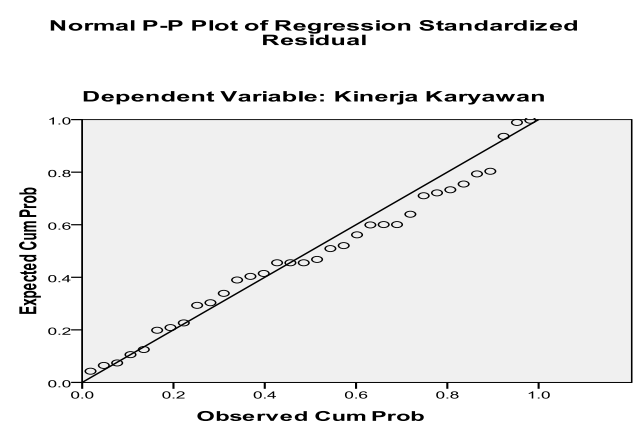

Sumber : Data Olahan SPPS. 17, 2019.

Dari gambar 5.1 dapat dilihat bahwa data menyebar disekitar dan mengikuti arah garis diagonal. Dapat diartikan bahwa model regresi memenuhi asumsi normalitas.

\section{Regresi Linear Sederhana}

Berdasarkan data dari 34 orang responden, setelah dilakukan pengujian adapun persamaan regresinya adalah dengan menggunakan rumus SPSS. 17.0 didapat nilai $\mathrm{a}=18,342, \mathrm{~b}=0,627$, maka persamaan regresi linear sederhana adalah sebagai berikut :

$$
Y=18,342+0,627 X
$$

Berdasarkan persamaan di atas maka :

1. Konstanta 18,342. Berarti saat kompetensi diabaikan atau nol maka kinerja karyawan sebesar 18,342 satuan.

2. Koefisien variabel kompetensi 0,627. Berarti jika variabel kompetensi di naikkan 1 satuan, maka kinerja karyawan pada PT. Bank Danamon Indonesia, Tbk Cabang Simpang Pasar Bawah akan naik sebesar 0,627 satuan. Koefisien variabel kompetensi bertanda positif. Berarti semakin baik kompetensi yang dimiliki karyawan maka kinerja karyawan pada PT. Bank Danamon Indonesia, Tbk Cabang Simpang Pasar Bawah akan lebih meningkat.

Uji t

Uji $\mathrm{t}$ digunakan untuk mengetahui apakah variabel independen secara parsial berpengaruh positif dan signifikan terhadap 
variabel dependen. Untuk melihat hasil uji t dapat dilihat dari tabel 6 berikut ini:

Tabel 6 Hasil Uji t

\begin{tabular}{|c|c|c|c|c|c|}
\hline \multirow[b]{3}{*}{ Model } & \multicolumn{5}{|c|}{ Coefficients $^{2}$} \\
\hline & Unstandardized & Coefficients & Standardized Coefficients & & \\
\hline & B & Std. Error & Beta & $\mathrm{t}$ & Sig. \\
\hline 1 (Constant) & 18.342 & 6.336 & & 2.895 & .007 \\
\hline Kompetensi & .627 & .128 & .656 & 4.915 & .000 \\
\hline
\end{tabular}

Sumber : Data Olahan SPSS. 17, 2019.

Dari tabel 6 dapat dilihat bahwa nilai $t_{\text {hitung }}$ kompetensi sebesar 4,915. Tingkat signifikan penelitian ini adalah $5 \%$ atau 0,025 (Uji 2 sisi). Untuk melakukan uji t maka dilakukan langkah-langkah sebagai berikut :

Tingkat signifikan penelitian ini adalah 5\% atau 0,025 (Uji 2 sisi). Berarti di dapat $t_{\text {tabel }}$ sebesar 2,037. Maka terbukti bahwa : Kompetensi $(\mathrm{X})=$ dengan $t_{\text {hitung }}$ 4,915 lebih besar dari $t_{\text {tabel }} 2,037$ dengan tingkat signifikan 0,000 lebih kecil dari 0,05. Maka Ho ditolak dan Ha diterima, artinya variabel kompetensi berpengaruh positif dan signifikan terhadap kinerja karyawan pada PT. Bank Danamon Indonesia, Tbk Cabang Simpang Pasar Bawah.

\section{Uji Analisis Determinasi $\left(\mathbf{R}^{\mathbf{2}}\right)$}

Untuk mengetahui besarnya pengaruh kompetensi terhadap kinerja karyawan pada PT. Bank Danamon Indonesia, Tbk Cabang Simpang Pasar Bawah digunakan koefisien determinasi $\left(\mathrm{R}^{2}\right)$, setelah dilakukan pengolahan data dapat dilihat pada tabel 7 berikut ini :

Tabel 7 Hasil R-square (Koefisien Determinan)

\begin{tabular}{|l|c|r|r|r|}
\hline & & & & \\
\hline Model & \multicolumn{1}{|c|}{$\mathrm{R}$} & R Square & Adjusted R Square & Std. Error of the Estimate \\
\hline 1 & $.656^{\mathrm{a}}$ & .430 & .412 & 3.73995 \\
\hline
\end{tabular}

Sumber : Data Olahan SPSS. 17, 2019.

Dari tabel 7 dapat diperoleh nilai $\mathrm{R}=0,656$.

Berarti kompetensi memiliki keeratan sebesar $65,6 \%$ terhadap kinerja karyawan sedangkan hasil r-square (koefisien determinasi) sebesar 0,430. Hal ini berarti kompetensi memberikan sumbangan pengaruh terhadap kinerja karyawan pada PT. Bank Danamon Indonesia, Tbk Cabang
Simpang Pasar Bawah sebesar 43\% sedangkan sisanya sebesar $(100 \%-43 \%)=$ $57 \%$ dipengaruhi oleh variabel lain diluar variabel dalam penelitian ini

\section{SIMPULAN}

Berdasarkan hasil penelitian yang telah dilakukan mengenai pengaruh kompetensi terhadap kinerja karyawan pada PT. Bank Danamon Indonesia, Tbk Cabang Simpang Pasar Bawah, maka berikut ini penulis mengambil kesimpulan yaitu :

1. Hasil deskriptif tanggapan responden terhadap variabel kompetensi dan variable kinerja karyawan adalah setuju.

2. Persamaan regresi linear sederhana adalah sebagai berikut : $\mathrm{Y}=18,342+$ 0,627X, maka dapat dilihat konstanta sebesar 18,342. Berarti saat kompetensi diabaikan atau nol maka kinerja karyawan sebesar 18,342, sedangkan lingkungan kerja (X) terhadap kinerja karyawan adalah positif terbukti dari hasil $b=0,627$ yang berarti bahwa setiap kenaikan kompetensi satu satuan akan dapat menaikan kinerja karyawan pada PT. Bank Danamon Indonesia, Tbk Cabang Simpang Pasar Bawah sebesar 0,627 satuan.

3. Variabel kompetensi $(\mathrm{X})$ dengan $\mathrm{t}_{\text {hitung }}$ 4,915 lebih besar dari $t_{\text {tabel }} 2,037$ dengan tingkat signifikan 0,000 lebih kecil dari 0,05. Maka Ho ditolak dan $\mathrm{Ha}$ diterima, artinya variabel kompetensi berpengaruh positif dan signifikan terhadap kinerja karyawan pada PT. Bank Danamon Indonesia, Tbk Cabang Simpang Pasar Bawah.

4. Nilai r-square (koefisien determinasi) sebesar 0,430. Hal ini menunjukkan bahwa kompetensi memberikan sumbangan pengaruh terhadap kinerja karyawan pada PT. Bank Danamon Indonesia, Tbk Cabang Simpang Pasar Bawah sebesar $43 \%$ sedangkan sisanya sebesar $(100 \%-43 \%)=57 \%$ dipengaruhi oleh variabel lain diluar variabel dalam penelitian ini. 
5. Dari hasil penelitian menunjukkan bahwa kompetensi berpengaruh positif dan signifikan terhadap kinerja karyawan pada PT. Bank Danamon Indonesia, Tbk Cabang Simpang Pasar Bawah. Hal ini sesuai dengan penelitian sebelumnya yang menyatakan bahwa kompetensi berpengaruh terhadap kinerja karyawan. Maka penelitian ini dapat menguatkan penelitian sebelumnya.

\section{DAFTAR RUJUKAN}

Arikunto, Suharsimi, 2010. Prosedur Penelitian, Edisi Revisi, Rineka Cipta, Jakarta.

Dharma Surya, 2012. Manajemen Kinerja, Cetakan V, Pustaka Pelajar, Jakarta.

Ellitan Lena\&Anatan Lina, 2009. Manajemen Inovasi Transformasi Menuju Organisasi Kelas Dunia, Cetakan I, Alfabeta, Bandung.

Fatimah, Siti Fira, 2015. Pengaruh Kompetensi Sumber Daya Manusia Terhadap Kinerja Karyawan (Studi Pada Kantor Pusat PT. Perkebunan Nusantara IV (Persero) Medan, Universitas Sumatera Utara, Medan.

Fitran, M. Ali, 2012. Pengaruh Kompetensi Terhadap Kinerja Karyawan Pada Level Jabatan Manajerial Studi Kasus Pada PT. Bank Syariah ABC, Universitas Indonesia, Jakarta.

Hasibuan, S.P Melayu, 2012. Manajemen Sumber Daya Manusia, Edisi Revisi, Cetakan XVI, PT. Bumi Aksara, Jakarta.

Kasmir, 2012. Pemasaran Bank, Edisi Revisi,Prenada Media, Jakarta.

Mangkunegara, A.A. Anwar Prabu, 2011. Manajemen Sumber Daya Manusia Perusahaan, PT. Remaja Rosdakarya, Bandung.

Manullang, M, 2009. Dasar-Dasar Manajemen, Cetakan ke XXI, Gadjah Mada University Press, Yogyakarta.

Notoatmodjo, $\quad$ Soekidjo, 2009. Pengembangan Sumber Daya Manusia, Rineka Cipta, Jakarta.
Palan, R. 2007. Competency Management Teknik Mengimplementasikan Manajemen SDM Berbasis Kompetensi untuk Meningkatkan Daya Saing Organisasi. Penerjemah: Octa Melia Jalal, PPM, Jakarta.

Priyatno, Duwi, 2008. Mandiri Belajar SPSS, Cetakan I, PT. Buku Kita, Jakarta.

Sugiyono, 2010. Metode Penelitian Administrasi, Cetakan XVIII, Alfabeta, Bandung.

Sutrisno, Edy, 2015. Manajemen Sumber Daya Manusia, Kencana Prenadamedia Group, Jakarta.

Soviana, Nelly, 2016. Pengaruh Kompetensi Terhadap Kinerja Karyawan Pada Bank Danamon Simpan Pinjam Unit Ps. Kota Duri, Sekolah Tinggi Ilmu Ekonomi Riau, Pekanbaru.

Sudarmanto, 2015. Kinerja Dan Pengembangan Kompetensi SDM, Cetakan Ketiga, Pustaka Pelajar, Yogyakarta.

Sunyoto, Danang, 2012. Teori Kuesioner Dan Analisa Data Sumber Daya Manusia, Cetakan I, CAPS, Yogyakarta.

Supardi, 2013. Kinerja Guru, PT. Raja Grafindo Persada, Jakarta.

Verayanti, Putu Deby, dkk, 2014. Pengaruh Kompetensi Sosial Terhadap Kinerja Pegawai Negeri Sipil Di Badan Kepegawaian Daerah Kabupaten Buleleng, Universitas Pendidikan Ganesha Singaraja, Indonesia.

Wibowo, 2007. Sistem Mananjemen Kinerja, PT. Raja Grafindo Persada, Jakarta. , 2013. Manajemen Kinerja, Edisi Ketiga, Cetakan VI, Rajawali Pers, Jakarta.

Wilson, Bangun, 2012. Manajemen Sumber Daya Manusia, Erlangga, Jakarta. 